\title{
Prostate Specific Antigen. Current clinical application and future prospects
}

\author{
Katerina Duskova, Stepan Vesely
}

\begin{abstract}
Background. Prostate-specific antigen (PSA) is a glycoprotein produced by the prostate gland and its production can be enhanced in benign and malignant diseases. The introduction of PSA testing has greatly increased the detection of prostate cancer. However there is continuing controversy and confusion over the most appropriate application of the PSA test.

Methods. PubMed and Web of Science databases were used to search original and review articles on the historical aspects, clinical utilization and possible future directions in PSA.

Conclusions. After its discovery, PSA was quickly established as an exquisitely sensitive tumor marker for prostate cancer detection, assessment of treatment responses and follow-up among patients with prostate cancer. Nevertheless, controversy exists about the proper threshold for recommending prostate biopsy. If this limit is lowered to improve the sensitivity even more, patients with low-risk prostate cancer would be subsequently detected. Post-treatment PSA levels can certainly provide valuable information about the effectiveness of the therapy given. Recently introduced ultrasensitive PSA detection techniques are offering new insight into the changes in serum PSA at very low concentrations. This has resulted in identification of valuable postoperative prognostic variables together with the possibility of earlier cancer relapse detection. The development of assays that may show superior sensitivity and specificity in prostate cancer diagnosis is focused on proteins possibly complexed with PSA and other potential markers detectable both in serum and urine. The goal of newly discovered prostate cancer biomarkers is greater cancer specificity in order to reduce the overdiagnosis, overtreatment and financial cost.
\end{abstract}

Key words: PSA, prostate cancer, biomarkers

Received: December 18, 2013; Accepted with revision: August 29, 2014; Available online: October 2, 2014 http://dx.doi.org/10.5507/bp.2014.046

${ }^{a}$ Department of Urology, $2^{\text {nd }}$ Faculty of Medicine, Charles University in Prague and University Hospital Motol, Czech Republic Corresponding author: Katerina Duskova, e-mail: katerina@duskovi.info

\section{HISTORY}

In the late 1960s, there was rapid progress in biochemical techniques leading to discovery of several antigens in various tissues and body fluids. At the same time, there was also a search to identify male-specific antigens in semen for forensic purposes. In 1971 Mitsuwo Hara and col. discovered $\gamma$-seminoprotein in human semen and two years later Tien Shun Li and Carl G Beling aimed at immunological control of fertility and they isolated E1 antigen. In 1978 George Sensabaugh discovered another perspective forensic marker for cases of rape named protein $\mathrm{p} 30$. These days we know that all these independently discovered proteins ( $\gamma$-seminoprotein, E1 and p30) are synonymous with prostate specific antigen (PSA) (ref. ${ }^{1}$ ). PSA was first measured quantitatively in the blood by Papsidero in 1980 and Stamey finished the initial work by reporting the correlation of PSA with the progression of prostate cancer in $1987\left(\right.$ ref. $\left.^{2}\right)$. This was the beginning of the clinical use of PSA which has gradually become the most widely used oncological biomarker in medicine today.

\section{BIOCHEMISTRY AND MECHANISM OF ACTION}

PSA is a kallikrein-like serine protease with low chymotrpysin-like enzymatic activity that is produced exclusively by the epithelial cells of all types of prostatic tissue, benign and malignant. Extraprostatic production of PSA is provided mainly by the periurethral glands, leading to measurable urine but undetectable serum levels of PSA in women and in men. The role of PSA is to liquefy the ejaculate by which the motility of sperms increases ${ }^{3}$. Glandular ducts usually provide efficient barriers to prevent the escape of high concentrations of PSA into the general circulation. The increase of PSA outflow into the serum is related to various disease states of the prostate, especially prostate cancer. Three major PSA fractions were discovered. The majority of serum PSA forms a complex with two serine protease inhibitors $\alpha 1$-antichymotrypsin and $\alpha 2$-macroglobulin. The rest of the serum PSA is considered to be biologically inactive and is called "free PSA". Currently used immunoassays are able to detect free PSA and PSA complex with $\alpha 1$ antichymotrypsin. 


\section{PSA AND PROSTATE CANCER}

When it was shown in the late 80's that the level of serum PSA correlates with the stage of prostate cancer, PSA was then rapidly identified as a useful marker for the follow-up of patients with prostate cancer. In 1986, PSA was approved by the USA Food and Drug Administration (FDA) to monitor prostate cancer and in 1994 PSA was approved as a tool for detecting the disease in men older than 50 years. Although PSA represents one of the most useful biomarkers for detection and management of prostate cancer it is not an ideal biomarker and causes many controversies. Despite relative widespread PSA screening, prostate cancer remains the second most common cause of cancer death in men. With an incidence rate of 214 cases per 100.000 men in Europe it has become the most common solid neoplasm outnumbering colorectal and lung cancer ${ }^{4}$.

The limitation of the PSA examination is its specificity. It is believed that prostate cancer cells have a changed structure, which causes the outflow of PSA into the serum in larger amounts compared to the normal prostate. However, even though PSA is organ-specific, it can be elevated not only by cancer of the prostatic gland, but also in non-malignant conditions such as benign prostatic hypertrophy and prostatitis ${ }^{5}$. Moreover, PSA levels are highly variable over time and can be affected by manipulations of the prostate ${ }^{6}$.

There are a number of PSA assays for detection available from various manufacturers. However, these do not detect PSA equally and several studies have shown variability between them ${ }^{7,8}$. The interpretation of PSA velocity influences clinical decisions because many men present today with sequential PSA determinations over several years. To harmonize PSA results and reduce the discrepancies between the various assays, reference materials are available for assay calibration. Method comparisons between the traditionally calibrated Hybritech PSA and fPSA assays and the new "standardized" WHO calibrated assays yield results that are lower for PSA and PPSA by $25 \%$. A PSA cut-off of 3 or $3.1 \mathrm{ng} / \mathrm{mL}$ should be considered for WHO calibrated assays in order to achieve the same sensitivity/specificity profile as with a cut-off of 4 $\mathrm{ng} / \mathrm{mL}$ in traditionally calibrated assays ${ }^{9}$. Further, as recently reviewed, the intraindividual biological variation of PSA may well reach $20 \%$ (ref. $^{10}$ ). Owing to such analytical and biological variations, PSA changes over time must be interpreted with great care.

\section{DETECTION OF PROSTATE CANCER}

The traditional threshold of $4.0 \mathrm{ng} / \mathrm{mL}$ was first proposed by Hybritech Inc. (San Diego, CA, USA) in 1986 after studying a cohort of men without prostate cancer ${ }^{11}$. This assay was the first PSA assay approved by the FDA $\left(\right.$ ref. $\left.^{12}\right)$. Consequently, a value of PSA $>4.0 \mathrm{ng} / \mathrm{mL}$ became established for recommending biopsy, although it was known that men could have cancer with PSA values below this threshold. Numerous recent studies have shown that a significant number of cancers are missed with this cutoff ${ }^{13}$. A PSA cut-off of $4.0 \mathrm{ng} / \mathrm{mL}$ has a sensitivity of $67-80 \%$, which implies that $20-30 \%$ of cancers are missed when only the PSA level is obtained ${ }^{14}$. In order to improve the sensitivity, a $2.5 \mathrm{ng} / \mathrm{mL}$ cutoff was recently recommended by the National Comprehensive Cancer Network (NCCN) in the United States. Several other modifications of PSA value are suggested to attain a better test sensitivity.

\section{Age-specific PSA}

The age-specific PSA reference range reflects the association between PSA and age. As men age, the value of their serum PSA increases. This seems to be due to the contribution of enlarged prostate as well as due to increased "leakiness" of the prostatic epithelium. This is thought to be a result of subclinical inflammation or microscopic foci of cellular atypia ${ }^{15}$. It is generally accepted that a PSA of 3.5 for a 50 -year-old man is more significant than a PSA value of 4.5 for a 70 -year-old $\operatorname{man}^{13}$. On other hand, age specific PSA has been shown to increase detection of prostate cancer in younger men (50-59 years) by $15 \%$, although at the cost of a $45 \%$ increase in the number of biopsies performed ${ }^{16}$. One trend in PSA detection is now a baseline PSA determination at age 40 years, upon which the following screening interval may then be based ${ }^{17}$, A subsequent screening interval of 8 years might be enough in men with initial PSA levels $<1$ $\mathrm{ng} / \mathrm{mL}\left(\right.$ ref. $^{18}$ ). In the USA, the NCCN suggests relating patient PSA to an age-specific median PSA. If the PSA is higher than the age-specific median, annual screening is recommended ${ }^{19}$.

\section{PSA density}

Another effective method is to include the size of the prostate, called PSA density. Men with enlarged prostates often have elevated PSA because of benign disease. PSA density can be calculated by dividing the PSA value by the prostate volume measured by TRUS (transrectal ultrasonography). The difficulty with this approach is that TRUS is invasive and expensive, and the prostate volumes determined at different medical centers may vary significantly $^{20}$. Not only the size of a whole gland, but also the transition zone of the gland can be measured diagnostically. One study showed the efficiencies of transition zone PSA density in the diagnosis of prostate cancer in men with a PSA $4-20 \mathrm{ng} / \mathrm{mL}\left(\right.$ ref. $\left.^{21}\right)$.

\section{PSA velocity}

Another clinical feature which may indicate the presence of prostate cancer is the rate of PSA increase with time, named PSA velocity. Serum PSA increases significantly in the presence of tumor compared with benign disease alone. On the one hand, PSA velocity analysis may not be practical because multiple PSA values must be obtained over a period of years to use this algorithm most effectively ${ }^{22}$. Prospective studies have shown that these measurements do not provide additional information compared to PSA alone ${ }^{23}$. 


\section{Free PSA}

Extensive research on free PSA has demonstrated that analysis of the proportions of the free-to-total PSA (f/t PSA) in serum may increase the diagnostic specificity by $15-20 \%$ and it is recommended for use in patients with PSA values between 4.0 and $10.0 \mathrm{ng} / \mathrm{mL}$. It was demonstrated that increased levels of free PSA are associated with benign prostate tissue and decreased probability of cancer ${ }^{24}$. In a prospective multicentre trial, tumor was found on biopsy in $56 \%$ of men with $\mathrm{f} / \mathrm{t}$ PSA $<0.10$, but in only $8 \%$ of men with $\mathrm{f} / \mathrm{t}$ PSA $>0.25\left(\right.$ ref. $\left.^{25}\right)$. However, the level of free PSA can be influenced by many factors such as the temperature instability of free PSA or the size of the gland above $40 \mathrm{~cm}^{3}$ (ref. ${ }^{26}$ ).

\section{SCREENING FOR PROSTATE CANCER}

PSA elevations lead to prostate biopsies which frequently uncover harmless forms of cancer without the possibility of distinguishing between a harmless and a potentially metastatic form. Hence, massive PSA screening is associated with the overtreatment of many men with indolent cancer. Despite this, the clinical use of PSA has caused a decrease in prostate cancer mortality mainly because of diagnosis in the earlier and curable clinical stages. According to The European Randomized Study of Screening for Prostate Cancer (ERSPC) PSA screening provides a $20 \%$ mortality reduction. However, in order to prevent one cancer specific death within a 9 year period, 1410 patients need to be screened from which 48 need to be treated ${ }^{27}$. Considering the longer time period, the benefit of screening is much higher - at year 12 only 503 man need to be screened and 18 man need to be treated to prevent one prostate cancer death ${ }^{28}$. The majority of new cases are clinically unapparent, localized and with a low Gleason score. To prevent overtreatment, it is necessary to understand the prolonged natural history of the disease; most patients are diagnosed at an older age. However, the clinical course of localized untreated prostate cancer is still unclear. Progression of the disease to the metastatic form in 10-15 years from diagnosis is not frequent ${ }^{29}$, but the further follow-up has shown that even primarily indolent localized prostate cancer can proceed to a more aggressive form ${ }^{30}$. According to the guidelines of the European Urological Society and based on the results of large, randomized trials widespread mass PSA screening is not appropriate. More suitable is the opportunistic screening offered to the well-informed man. It is recommended to start the screening at 40 years. If the PSA levels are below $1 \mathrm{ng} / \mathrm{mL}$, further screening every 8 years is enough. Men older than 75 years should not be screened because the early detection of the tumor would not have any clinical impact ${ }^{17,18}$.

\section{PSA AS A PREDICTOR OF TREATMENT SUCCESS}

The pretreatment PSA serum level is considered to be a predictor of the response to radical prostatectomy or radiotherapy. In several studies where multivariable predictive models were constructed, PSA proved to be an independent prognostic factor. One of the most established risk group stratifications was presented by D'Amico. By means of PSA, biopsy Gleason score and clinical stage patients were divided by into the three risk groups according to the different probability of biochemical relapse after surgery or radiotherapy: low (clinical stage T1c-T2a and PSA $<10 \mathrm{ng} / \mathrm{mL}$ and GS $\leq 6$ ), intermediate (clinical stage T2b or PSA level of $10.1-20 \mathrm{ng} / \mathrm{mL}$ or GS 7) and high risk group (clinical stage T2c or PSA $>20 \mathrm{ng} / \mathrm{mL}$ or GS 8-10) (ref. ${ }^{31}$ ) This stratification predicts the probability of biochemical relapse in 5 years after the curative therapy to be $<25 \%, 25-50 \%$ and $>50 \%$ respectively. The published literature describes several predictive algorithms, multivariate analyses and artificial neural networks incorporating preoperative PSA as a means to estimate the risk of prostate cancer progression ${ }^{32,33}$. The predictive accuracy of the most widely used preoperative model for prediction of biochemical recurrence after radical prostatectomy ranges from $67 \%$ to $86 \%\left(\right.$ ref. $\left.^{34}\right)$. Despite better understanding of the biological behavior of prostate cancer, further improvement in the accuracy of existing models is limited by the lack of additional readily available predictive variables.

\section{PSA IN THE FOLLOW-UP AFTER THE THERAPY}

Monitoring of PSA in patients after definitive therapy is clinically very useful and widely accepted. After radical prostatectomy, the PSA level should decrease to undetectable levels. If not, the presence of local disease or metastasis is highly probable. Right after the radical surgery, the PSA level starts to decrease rapidly, and in 6-8 weeks after the prostatectomy, the PSA value of patients without residual disease should be undetectable - this means $<0.1$ $\mathrm{ng} / \mathrm{mL}$ according to most conventional assays ${ }^{35}$. During the follow-up of 10 years after the surgery about $35 \%$ of patients will experience a rise in PSA which is the first sign of progression of the disease after the prostatecto$\mathrm{my}^{36}$. Consistently rising PSA levels confirm a suspicion of biochemical recurrence. This point usually precedes metastatic disease progression and prostate cancer-specific mortality by about 7 and 15 years, respectively ${ }^{33}$. Characterization of the biochemical recurrence PSA level has numerous definitions which is depicted in Table 1. In the medical literature, however, the most frequently used PSA cut-off point is $0.2 \mathrm{ng} / \mathrm{mL}$. When PSA rises to this level, the patient is a candidate for an additional treatment - local radiotherapy (for believed local recurrence) or hormonal therapy (when believed to have metastatic disease). It is difficult to distinguish between the local or distant recurrence; however some parameters can help in order to differentiate them. PSA rises within the first 2 years following surgery or shorter PSA-doubling times are more often associated with distant recurrences, whereas longer PSA-doubling time suggest local failure $e^{37,38}$.

After radiotherapy, the decline of serum PSA is slower compared with radical prostatectomy. The PSA nadir is reached approximately in 18 months, and undetectable 
Table 1. Various definitions of biochemical recurrence after radical prostatectomy used in clinical practice.

\begin{tabular}{ll}
\hline BCR Definition & Description \\
\hline PSA $\geq 0.6 \mathrm{ng} / \mathrm{L}$ & Single PSA $\geq 0.6 \mathrm{ng} / \mathrm{L}$ \\
PSA $\geq 0.4 \mathrm{ng} / \mathrm{L}$ & Single PSA $\geq 0.4 \mathrm{ng} / \mathrm{L}$ \\
$\mathrm{PSA} \geq 0.4 \mathrm{ng} / \mathrm{L}$ and rising & $\mathrm{PSA} \geq 0.4 \mathrm{ng} / \mathrm{L}$ followed by a value higher than the first \\
$\mathrm{PSA} \geq 0.2 \mathrm{ng} / \mathrm{L}$ & Single PSA $\geq 0.2 \mathrm{ng} / \mathrm{L}$ \\
$\mathrm{PSA} \geq 0.2 \mathrm{ng} / \mathrm{L}$ and rising & PSA $\geq 0.2 \mathrm{ng} / \mathrm{L}$ followed by a value higher than the first \\
2 successive rises, final PSA $\geq 0.2 \mathrm{ng} / \mathrm{L}$ & 2 successive rises by any incremental amount, final PSA value $\geq 0.2 \mathrm{ng} / \mathrm{L}$ \\
PSA $\geq 0.1 \mathrm{ng} / \mathrm{L}$ and rising & PSA $\geq 0.1 \mathrm{ng} / \mathrm{L}$ followed by value higher than the first \\
3 successive rises & 3 successive rises by any incremental amount \\
3 successive rises $\geq 0.1 \mathrm{ng} / \mathrm{L}$ & 3 successive incremental PSA rises of $0.1 \mathrm{ng} / \mathrm{mL}$ or greater \\
3 consecutive rises & 3 consecutive PSA rises by any incremental amount \\
\hline
\end{tabular}

PSA (prostate specific antigen), BCR (biochemical recurrence)

Table 2. Summary of studies proving the significant capability $(P<0.001)$ of ultrasensitive PSA nadir to predict BCR after radical prostatectomy.

\begin{tabular}{lcccc}
\hline Study & Year & $\begin{array}{c}\text { Number } \\
\text { of patients }\end{array}$ & $\begin{array}{c}\text { Median } \\
\text { of follow-up }\end{array}$ & $\begin{array}{c}\text { PSA nadir cut-off } \\
\text { for predicting BCR }\end{array}$ \\
\hline Doherty AP et al. $\left(\right.$ ref $^{86}$ ) & 2000 & 200 & 1.7 years & $>0.01$ \\
Nakamura M et al. $\left(\right.$ ref. $^{87}$ ) & 2005 & 46 & 2.5 years & $>0.01$ \\
Shen S et al. $\left(\right.$ ref. $^{88}$ ) & 2005 & 906 & 3.1 years & $>0.01$ \\
Sakai I et al. (ref. & ) & 127 & 2.6 years & $\geq 0.01$ \\
Kinoshita H et al. $\left(\right.$ ref. $^{90}$ ) & 2006 & 257 & 4.4 years & $>0.01$ \\
Eisenberg ML et al. $\left(\right.$ ref. $\left.^{91}\right)$ & 2010 & 525 & 4.7 years & $>0.05$ \\
Hong SK et al. $\left(\right.$ ref. $^{46}$ ) & 2010 & 384 & 3.3 years & $>0.001$ \\
Yoshida T et al. $\left(\right.$ ref. $^{92}$ ) & 2012 & 102 & 2.6 years & $>0.01$ \\
Vesely S et al. $\left(\right.$ ref. $^{93}$ ) & 2013 & 319 & $\geq 2$ years & $>0.01$ \\
\hline
\end{tabular}

PSA (prostate specific antigen), BCR (biochemical recurrence)

PSA levels are not usually achieved ${ }^{37}$. However, a PSA nadir below $0.5 \mathrm{ng} / \mathrm{mL}$ seems to be associated with a favorable outcome ${ }^{38}$. Current definitions of biochemical failure after radiotherapy are PSA rising more than $2 \mathrm{ng} /$ $\mathrm{mL}$ above the PSA nadir ${ }^{39}$. Despite all these findings, for many patients the rise in PSA does not represent a threat to their life-expectancy or their quality of life. Within 15 years of biochemical recurrence patients are as likely to die from prostate cancer as from other causes ${ }^{40}$.

PSA monitoring during the hormonal therapy is used for patients with either metastatic or locally advanced prostate cancer. The initial PSA level reflects the extent of the disease but poorly differentiated tumors can produce only a small amount. The effect of the hormonal therapy correlates with the PSA nadir and with the time to PSA nadir. In fact, the sooner and the lower the PSA nadir is, the better the survival ${ }^{41,42}$. A rising PSA in a hormonally treated patient, even if the values are within the "normal" range, signals clinical progression and second-line therapy is needed.

Even in case of hormonally independent metastatic tumor, PSA is a marker of response to the chemotherapy. However there are some controversies about the value of PSA response for non-hormonal noncytotoxic drugs.
Some of them demonstrated a significant overall-survival benefit without a PSA decline ${ }^{43}$.

\section{ULTRASENSITIVE PSA}

Recent advances in technology have made it possible to measure PSA at much lower levels. Thus, it has been demonstrated that the "biological zero" level of PSA after surgery is much lower than with the use of conventional assays. Several authors have shown that by using a time-resolved immunofluorometric, the PSA assay system with a detection limit under $0.01 \mathrm{ng} / \mathrm{mL}$, patient relapse could be discovered earlier by several months or years than by using conventional assays with detection limits of $0.1 \mathrm{ng} / \mathrm{mL}$ or higher ${ }^{44}$. Early detection of recurrence offers the possibility of salvage therapy which can be initiated sooner and more favorable outcomes can be expected ${ }^{44}$. In general, assays that measure PSA to levels under $0.01 \mathrm{ng} / \mathrm{mL}$ are referred to as "ultrasensitive" or third-generation because they are $2 \operatorname{logs}$ more sensitive than the first generation of PSA (ref. ${ }^{45}$ ). With the introduction of ultrasensitive PSA assays, various potential predictive parameters indicating treatment failure were discovered ${ }^{46}$. The absolute 
lowest level of PSA (PSA nadir) measured with a sensitive assay offers the possibility of confidently predicting the removal of all significant PSA producing tissue within a few weeks of the operation. This parameter can even give the patient an idea as to how likely he is to have recurrent prostate cancer. Table 2 shows a list of studies finding an ultrasensitive PSA nadir as an independent predictor for biochemical recurrence after radical prostatectomy. This can significantly improve the identification of patients who are at high risk of disease recurrence after the surgery. Despite this evidence, most contemporary guidelines do not uniformly recommend clinical use of ultrasensitive PSA tests. According to some authors, ultrasensitive PSA assay is not reliable and insignificant oscillation of its level can cause unnecessary anxiety among patients ${ }^{47}$.

\section{NEW TRENDS IN PSA DETECTION}

Limitation in sensitivity and specificity of PSA leads to many attempts to improve the accuracy of detection, management and prognosis of patients with prostate cancer. Various forms of PSA or novel biomarkers associated with PSA in both serum and urine are at early stages of development and require evaluation in prospective trials to determine their potential usefulness in clinical practice.

\section{PCA3}

One of these promising markers is PCA3 (also known as DD3). This gene is 60 to 100 -fold overexpressed in $95 \%$ of prostate cancer compared with normal or benign hyperplastic prostate ${ }^{48}$. The expression of this gene is measured in the urine of men with suspicion of prostate cancer and is compared with the expression of the PSA gene. A PCA3 score $>35$ in the urine is correlated with an average sensitivity and specificity of $66 \%$ and $76 \%$, respectively, for the diagnosis of PCa (compared to a specificity of $47 \%$ for serum PSA at the cutoff for $65 \%$ sensitivity) (ref. ${ }^{49}$ ). Progensa PCA3 (Gen-Probe Inc., San Diego, CA, USA) is a commercially available diagnostic test that quantitatively detects $P C A 3$ RNA expression in urine and could be clinically helpful in determining which patients should be biopsied ${ }^{50,51}$.

\section{AMACR}

Another urine test is based on the detection of a gene, alpha-methyl coenzyme A racemase (AMACR). Zielie and associates demonstrated that quantification of AMACR transcripts normalized to PSA transcripts in urine sediments was highly predictive of prostate can$\operatorname{cer}^{52}$. The discovery of TMPRSS2:ERG gene fusions in the urine of prostate cancer patients provides a powerful new noninvasive approach to cancer detection ${ }^{53}$. Such gene translocations may be not only diagnostic but also causative for the development of prostate cancer.

\section{ProPSA}

Clinical studies over the last decade have suggested potential clinical applications for PSA forms and the related kallikrein hK2. These markers may have a potential clinical value, especially the pro-enzyme form of PSA (proPSA). This molecule represents one component of the free PSA and contains the pro-leader peptide which is removed by human kallikrein 2 before becoming PSA. Pro-PSA is enzymatically inactive and its level is higher in patients with prostate cancer. However, further studies are needed to consider its clinical use ${ }^{54}$.

\section{BPSA}

BPSA presents another free PSA form which was recently discovered. It has been shown that BPSA is closely correlated with benign prostatic hyperplasia ${ }^{55}$. Thus, BPSA and proPSA represent benign and cancerassociated forms of PSA. Specific monoclonal antibodies to BPSA and proPSA have recently been used to develop specific immunoassays for the different free PSA molecular forms ${ }^{56}$. ProPSA is mostly detectable in peripheral zone tumors, while BPSA is enriched in the transition zone, especially in enlarged glands with benign hyperplastic nodules.

\section{inPSA}

A third molecular form of free PSA, inPSA (intact, nonnative PSA), has been identified in tissue and serum. Unlike BPSA and proPSA, the molecular characterization of inPSA is not known. The proportion of inPSA in serum is elevated in cancer-free tissue and tends to be the inverse of proPSA ${ }^{56}$.

\section{PSA-I}

PSA-I presents another specific monoclonal antibody to a free PSA form but it detects only the nonclipped forms of free PSA (ref. ${ }^{57}$ ). Thus, the PSA-I assay will be probably detecting both proPSA and inPSA but not BPSA. Studies with PSA-I have yielded encouraging results for the detection of prostate cancer. So far, there is no current immunoassay for inPSA but there is a possibility of calculation using free PSA, BPSA, and proPSA values.

\section{EPCA-2}

Early prostate cancer antigen-2 (EPCA-2) is a nuclear protein which is currently under intensive research. It seems that this antigen can be used not only in diagnostic but it may also enable us to distinguish localized prostate cancer from advanced cancer ${ }^{58}$.

\section{PSMA}

PSMA (prostate-specific membrane antigen) also called GCPII (glutamate carboxypeptidase II), is another highly specific tumor marker of prostate cancer. The potential of PSMA lies in the correlations between its expression, the differentiation of the tumor and angiogenesis ${ }^{59}$. As PSMA is a membrane-bound antigen, its detection in serum implies the presence of circulating prostate cells.

\section{MSMB}

Recently, the Microseminoprotein-beta (MSMB) gene was found to correlate with an increased risk of developing prostate cancer. This gene as one of the most abun- 
dant prostatic proteins can be reliably detected in tissue and serum. It seems that MSMB has potential as a biomarker of prostate cancer and potentially as a target for therapeutic intervention ${ }^{60}$.

\section{TMPRSS2-ERG}

The transmembrane protease, serine 2 v-ets erythroblastosis virus E26 oncogene homolog (avian) (TMPRSS2$E R G)$ translocation is present in many prostate cancers ${ }^{61}$. Detection of the TMPRSS2:ERG in urine has been reported to yield $>90 \%$ specificity and $94 \%$ positive predictive value for prostate cancer detection ${ }^{62}$. However, a clinical diagnostic test is not yet available.

\section{Urinary PSA}

In 1985 Graves and col. Demonstrated the presence of PSA in urine, since then there is still no consensus about the possible role of urinary PSA in the diagnosis or follow-up ${ }^{63}$. According to some studies urinary PSA does not reflect any serum value, however the urinary PSA as a ratio with a serum PSA has been proved a useful test in prostate cancer detection especially when the total serum PSA level is between 4 and $10 \mathrm{ng} / \mathrm{mL}^{64,65}$.

\section{Urinary thiosulfate}

Chwatko et al. used thiosulfate in urine as a new biomarker and confirmed about 6 times higher level of urinary thiosulfate among prostate cancer patients compared with patients suffering from benign prostate hyperplasia ${ }^{66}$. However thiosulfate has not been identified in the prostate cancer tissue as differentially expressed metabolite in malignant and benign prostate samples ${ }^{67}$.

\section{GENETIC MARKERS}

Accessibility at any age and stability in changing conditions are the biggest advantages of genetic markers. It is known that genetic factors are likely to contribute to survival in prostate cancer ${ }^{68,69}$. However, despite the large number of studies trying to determine a major prostate cancer susceptibility gene, this has not been found yet. Even in the case of "hereditary prostate cancer" multiple genes with a small to moderate effect seem to be involved ${ }^{70}$. Basically there are two types of genes affecting cancerogenesis - oncogenes and tumor-suppressors. The growth of the tumor cells is inhibited by tumor-suppressor genes, which can be inactivated by mutation, methylation of the promoter or by modification of the protein product. Oncogenes are derived from proto-oncogenes because of genetic damage. Proto-oncogenes are part of normal growth and proliferation of cells but in case of alteration they cause abnormal cell growth ${ }^{71}$.

\section{C-MYC}

cMYC proto-oncogen encodes the c-MYC protein - a transcription factor which promotes cell proliferation and differentiation $^{72}$. Amplification and overexpression of this gene correlates with Gleason grade and poor prognosis in advanced prostate cancer, however there has not been proven any correlation with overall survival ${ }^{73,74}$.

\section{C-ErbB2}

Also known as Her-2 neu encodes a transmembrane phosphoprotein. According to some studies overexpression of this gene correlates with progression of the disease to androgen independence. Because other studies have not shown any Her-2 neu amplification or overexpression in prostate cancer, there is still a controversy over the role of this gene ${ }^{75,76}$.

\section{Bcl-2}

Bcl-2 gene inhibits the apoptotic pathway ${ }^{77}$. Its overexpression has been implicated in the development of androgen independence and is associated with poor prognosis of disease ${ }^{78}$.

\section{PSCA (Prostate stem cell antigen)}

Strong PSCA expression has been found in more than $80 \%$ of prostate cancer and increased in higher Gleason score, higher tumor stage and progression to androgenindependence ${ }^{79,80}$.

\section{P53}

P53 gene is a tumor suppressor gene and is the most frequently mutated gene in human cancers. Its function is the prohibition of entrance into the synthetic phase of the cell cycle and the promotion of apoptosis in cells with damaged DNA (ref. ${ }^{81}$ ). Inactivation of p53 contributes to the genesis and progression of carcinoma. Abnormal nuclear p53 accumulation is observed in prostate tumors and is related to disease stage. It is also correlated with reduced survival after radical prostatectomy ${ }^{82,83}$.

\section{PTEN}

The gene PTEN (phosphatase and tensin homologue deleted on chromosome ten) encodes a phospholipid phosphatase which acts as a tumor suppressor gene by inhibiting the signaling pathway regulating cell cycle progression and cell survival ${ }^{84}$. PTEN is expressed in normal prostatic epithelial cells. In prostatic cancer its production is reduced particularly in high grade or stage ${ }^{85}$.

\section{CONCLUSIONS}

For decades PSA has been used to assist in the prostate cancer diagnosis and management. Although the number of deaths related to prostate cancer has appreciably decreased, it is not clear that this is solely due to PSA, whose clinical utility is surrounded by several controversies. There is no level of PSA that can reliably distinguish patients with prostate cancer from those without. Thus introduction of PSA screening has apparently led to the diagnosis of many clinically insignificant prostate cancers and subsequent aggressive treatment without obvious clinical benefit. Moreover, there is a lack of surrogacy between PSA changes and clinically significant signs of 
treatment efficacy. Recently introduced ultrasensitive PSA detection techniques offer new insight into posttreatment changes in serum PSA at very low concentrations. This may enable earlier cancer relapse detection as well as unnecessary anxiety among some patients. A new generation of superior prostate cancer markers have emerged, introducing new assays in serum and urine that may have higher cancer specificity than conventional PSA. This provides an opportunity to apply these findings to guide clinical decision making and thus reduce overdiagnosis, overtreatment and financial cost.

\section{ACKNOWLEDGEMENT}

Authorship contributions: KD: manuscript writing, KD, SV: final approval.

Conflict of interest statement: None declared.

\section{REFERENCES}

1. Sokoll LJ, Chan DW. Prostate-specific antigen: its discovery and biochemical characteristic. Urol Clin North Am 1997;24(2):253-9.

2. Stamey TA, Yang N, Hay AR, McNeal JE, Freiha FS, Redwine E. Prostate-specific antigen as a serum marker for adenocarcinoma of the prostate. N Engl J Med 1987;317(15):909-16.

3. Lilja H. Structure and function of prostatic and seminal vesicle-secreted proteins involved in the gelation and liquefaction of human semen. Scand J Clin Lab Invest Suppl 1988;191:13-20.

4. Jemal A, Siegel R, Ward E, Hao Y, Xu J, Murray T, Thun MJ. Cancer statistics, 2008. CA Cancer J Clin 2008;58(2):71-96.

5. JE., Oesterling. Prostate specific antigen: a critical assessment of the most useful tumor marker for adenocarcinoma of the prostate. J Uro 1991;145(5):907-23.

6. Oesterling JE, Chan DW, Epstein Jl, Kimball AW Jr, Bruzek DJ, Rock RC Bendler CB, Walsh PC. Prostate specific antigen in the preoperative and postoperative evaluation of localized prostatic cancer treated with radical prostatectomy. J Urol 1988;139(4):766-722.

7. Kort SA, Martens F, Vanpoucke $H$, van Duijnhoven $H L$, Blankenstein MA. Comparison of 6 automated assays for total and free prostatespecific antigen with special reference to their reactivity toward the WHO 96/670 reference preparation. Clin Chem 2006;52(8):1568-74.

8. Roddam AW, Rimmer J, Nickerson C, Ward AM. Prostate-specific antigen: bias and molarity of commercial assays for PSA in use in England. Ann Clin Biochem 2006;43(1):35-48.

9. Stephan C, Köpke T, Semjonow A, Lein M, Deger S, Schrader M, Miller K, Jung K. Discordant total and free prostate-specific antigen (PSA) assays: does calibration with WHO reference materials diminish the problem? Clin Chem Lab Med 2009;47(11):1325-31.

10. Soletormos G, Semjonow A, Sibley PE. Biological variation of total prostate-specific antigen: a survey of published estimates and consequences for clinical practice. Clin Chem 2005;51(8):1342-51.

11. Fitzpatrick JM, Banu E, Oudard S. Prostate-specific antigen kinetics in localized and advanced prostate cancer. BJU Int 2009;103(5):578-87.

12. Blanchet J, Brinkmann T. The Clinical Impact of WHO Standardization of PSA Assays. J Med Biochem 2008;27:161-8.

13. Thompson IM, Pauler DK, Goodman PJ, Tangen CM, Lucia MS, Parnes HL, Minasian LM, Ford LG, Lippman SM, Crawford ED, Crowley JJ, Coltman CA Jr. Prevalence of prostate cancer among men with a prostate-specific antigen level < or $=4.0 \mathrm{ng}$ per milliliter. $\mathrm{N}$ Engl J Med 2004;350(22):2239-46.

14. Chappell B, McLoughlin J. Technical considerations when obtaining and interpreting prostatic biopsies from men with suspicion of early prostate cancer: part I. BJU Int 2005;95(8):1135-40.

15. Oesterling JE, Cooner WH, Jacobsen SJ, Guess HA, Lieber MM. Influence of patient age on the serum PSA concentration. An important clinical observation. Urol Clin North Am 1993;20(4):671-80.
16. Catalona WJ, Hudson MA, Scardino PT, Richie JP, Ahmann FR, Flanigan RC, deKernion JB, Ratliff TL, Kavoussi LR, Dalkin BL. Selection of optimal prostate specific antigen cutoffs for early detection of prostate cancer: receiver operating characteristic curves. J Urol 1994;152(6Pt1):2037-42.

17. Börgermann $C$, Loertzer $H$, Hammerer $P$, Fornara $P$, Graefen $M$ Rübben $\mathrm{H}$. [Problems, objective, and substance of early detection of prostate cancer]. Urologe A 2010;49(2):181-9.

18. Roobol MJ, Roobol DW, Schröder FH. Is additional testing necessary in men with prostate-specific antigen levels of $1.0 \mathrm{ng} / \mathrm{mL}$ or less in a population-based screening setting? (ERSPC, section Rotterdam). Urology 2005;65(2):343-6.

19. S. Loeb, K.A. Roehl, J.A. Antenor, W.J. Catalona, B.K. Suarez, R.B. Nadler. Baseline prostate-specific antigen compared with median prostate-specific antigen for age group as predictor of prostate cancer risk in men younger than 60 years old. Urology 2006;67:316

20. Matthews GJ, Motta J, Fracehia JA. The accuracy of transrectal ultrasound prostate volume estimation: clinical correlations. J Clin Ultrasound 1996;24(9):501-5.

21. Tang P, Du W, Xie K, Deng X, Fu J, Chen H, Yang W. Transition zone PSA density improves the prostate cancer detection rate both in PSA 4.010.0 and 10.1-20.0 ng/ml in Chinese men. Urol Oncol 2013;31(6):7448.

22. Vickers AJ, Till C, Tangen CM, Lilja H, Thompson IM. An empirical evaluation of guidelines on prostate-specific antigen velocity in prostate cancer detection. J Natl Cancer Inst 2011;103(6):462-9.

23. O'Brien MF, Cronin AM, Fearn PA, Smith B, Stasi J, Guillonneau B, Scardino PT, Eastham JA, Vickers AJ, Lilja H. Pretreatment prostatespecific antigen (PSA) velocity and doubling time are associated with outcome but neither improves prediction of outcome beyond pretreatment PSA alone in patients treated with radical prostatectomy. J Clin Oncol 2009;27(22):3591-7.

24. De Angelis G, Rittenhouse HG, Mikolajczyk SD, Blair Shamel L, Semjonow A. Twenty Years of PSA: From Prostate Antigen to Tumor Marker. Rev Urol 2007;9(3):113-23.

25. Catalona WJ, Partin AW, Slawin KM, Brawer MK, Flanigan RC, Patel A Richie JP, deKernion JB, Walsh PC, Scardino PT, Lange PH, Subong EN, Parson RE, Gasior GH, Loveland KG, Southwick PC. Use of the percentage of free prostate-specific antigen to enhance differentiation of prostate cancer from benign prostatic disease: a prospective multicenter clinical trial. JAMA 1998;279(19):1542-7.

26. Stephan C, Lein M, Jung K, Schnorr D, Loening SA. The influence of prostate volume on the ratio of free to total prostate specific antigen in serum of patients with prostate carcinoma and benign prostate hyperplasia. Cancer 1997;79(1):104-9.

27. Schröder FH, Hugosson J, Roobol MJ, Tammela TL, Ciatto S, Nelen V, Kwiatkowski M, Lujan M, Lilja H, Zappa M, Denis LJ, Recker F, Berenguer A, Määttänen L, Bangma CH, Aus G, Villers A, Rebillard X, van der Kwast T, Blijenberg BG, Moss SM, de Koning HJ, Auvinen A. Screening and prostate-cancer mortality in a randomized European study. N Engl J Med 2009;360(13):1320-8.

28. Loeb S, Vonesh EF, Metter EJ, Carter HB, Gann PH, Catalona WJ. What is the true number needed to screen and treat to save a life with prostate-specific antigen testing? J Clin Oncol 2011;29(4):464-7.

29. Chodak GW, Thisted RA, Gerber GS, Johansson JE, Adolfsson J, Jones GW, Chisholm GD, Moskovitz B, Livne PM, Warner J. Results of conservative management of clinically localized prostate cancer. $\mathrm{N}$ Engl J Med 1994;330(4):242-8.

30. Bill-Axelson A, Holmberg L, Ruutu M, Garmo H, Stark JR, Busch C, Nordling $S$, Häggman $M$, Andersson SO, Bratell S, Spångberg $A$, Palmgren J, Steineck G, Adami HO, Johansson JE. Radical prostatectomy versus watchful waiting in early prostate cancer. N Engl J Med 2011;364(18):1708-17.

31. D'Amico AV, Ehittington R, Malkowicz SB, Schultz D, Blank K, Broderick GA, Tomaszewski JE, Renshaw AA, Kaplan I, Beard CJ, Wein A. Biochemical outcome after radical prostatectomy, external beam radiation therapy, or interstitial radiation therapy for clinically localized prostate cancer. JAMA 1998;280(11):969-74.

32. Stephenson AJ, Scardino PT, Eastham JA, Bianco FJ Jr, Dotan ZA DiBlasio CJ, Reuther A, Klein EA, Kattan MW. Postoperative nomogram predicting the 10-year probability of prostate cancer recurrence after radical prostatectomy. J Clin Oncol 2005;23(28):7005-12.

33. Freedland SJ, Humphreys EB, Mangold LA, Eisenberger M, Dorey FJ, Walsh PC, Partin AW. Risk of prostate cancer-specific mortality fol- 
lowing biochemical recurrence after radical prostatectomy. JAMA 2005;294(4):433-9.

34. Lughezzani G, Briganti A, Karakiewicz PI, Kattan MW, Montorsi F, Shariat SF, Vickers AJ. Predictive and prognostic models in radical prostatectomy candidates: a critical analysis of the literature. Eur Urol 2010;58(5):687-700.

35. Semjonow A, Hamm M, Rathert P. Prediction of tumor recurrence after radical prostatectomy using elimination kinetics of prostatespecific antigen. World J Urol 1993;11(4):218-20.

36. Roehl Ka, Han M, Ramos CG, Antenor JA, Catalona WJ. Cancer progression and survival rates following anatomical radical retropubic prostatectomy in 3478 consecutive patients: long-term results. $J$ Urol 2004;172(3):910-4.

37. Partin AW, Pearson JD, Landis PK, Carter HB, Pound CR, Clemens JO Epstein JI, Walsh PC. Evaluation of serum prostate-specific antigen velocity after radical prostatectomy to distinguish local recurrence from distant metastases.Urology 1994;43(5):649-59.

38. Oefelein MG, Smith N, Carter M, Dalton D, Schaeffer A. The incidence of prostate cancer progression with undetectable serum prostate specific antigen in a series of 394 radical prostatectomies. J Uro 1995; 154(6):2128-31.

39. Roach M 3rd, Hanks G, Thames H Jr, Schellhammer P, Shipley WU, Sokol GH, Sandler H. Defining biochemical failure following radiotherapy with or without hormonal therapy in men with clinically localized prostate cancer: recommendations of the RTOG-ASTRO Phoenix Consensus Conference. Int J Radiat Oncol Biol Phys 2006;65(4):965-74

40. Bianco FJ Jr., Scardino PT, Eastham JA. Radical prostatectomy: Longterm cancer control and recovery of sexual and urinary function ("trifecta"). Urology 2005;66(5):83-94.

41. Petros JA, Andriole GL. Serum PSA after antiandrogen therapy. Urol Clin North Am 1993;20(4):749-56.

42. Hussain M, Tangen CM, Higano C, Schelhammer PF, Faulkner J, Crawford ED, Wilding G, Akdas A, Small EJ, Donnelly B, MacVicar G, Raghavan D and (INT-0162), Southwest Oncology Group Trial 9346. Absolute prostate-specific antigen value after androgen deprivation is a strong independent predictor of survival in new metastatic prostate cancer: data from Southwest Oncology Group Trial 9346 (INT-0162). J Clin Oncol 2006;24(24):3984-90.

43. Bellmunt J, Rosenberg JE, Choueiri TK. Recent progress and pitfalls in testing novel agents in castration-resistant prostate cancer. Eur Urol 2009;56(4):606-8.

44. Boccon-Gibod L. pT3 prostate cancer: The case for salvage (as opposed to adjuvant) radiation therapy. Eur Urol Suppl 2007;54(3):541-

45. Bock JL, Klee GG. How sensitive is a prostate specific antigen measurement? How sensitive does it need to be? Arch Pathol Lab Med 2004; 128:341-3.

46. Hong SK, Park HZ, Lee WK, Kim DS, Lee JS, Doo SH, Jeong SJ, Yoon CY, Byun SS, Lee SE. Prognostic significance of undetectable ultrasensitive prostate-specific antigen nadir after radical prostatectomy. Urology 2010;76(3):723-7.

47. Taylor JA III, Koff SG, Dauser DA, McLeod DG. The relationship of ultrasensitive measurements of prostate-specific antigen levels to prostate cancer recurrence after radical prostatectomy. BJU Int 2006;98(3):540-3.

48. Salagierski M, Schalken JA. Molecular diagnosis of prostate cancer: PCA3 and TMPRSS2:ERG gene fusion. J Urol 2012;187(3):795-801.

49. van Gils MP, Hessels $D$, van Hooij $O$, Jannink SA, Peelen WP, Hanssen SL, Witjes JA, Cornel EB, Karthaus HF, Smits GA, Dijkman GA, Mulders $\mathrm{PF}$, Schalken JA. The time-resolved fluorescence-based PCA3 test on urinary sediments after digital rectal examination; a Dutch multicenter validation of the diagnostic performance. Clin Cancer Res 2007;13:939-43.

50. Groskopf J, Aubin SM, Deras IL, Blase A, Bodrug S, Clark C, Brentano S, Mathis J, Pham J, Meyer T, Cass M, Hodge P, Macairan ML, Marks LS, Rittenhouse H. APTIMA PCA3 molecular urine test: development of a method to aid in the diagnosis of prostate cancer. Clin Chem 2006;52(6):1089-95.

51. van Gils MP, Hessels D, van Hooij O, Jannink SA, Peelen WP, Hanssen SL, Witjes JA, Cornel EB, Karthaus HF, Smits GA, Dijkman GA, Mulders $\mathrm{PF}$, Schalken JA. The time-resolved fluorescence-based PCA3 test on urinary sediments after digital rectal examination; a Dutch mul- ticenter validation of the diagnostic performance. Clin Cancer Res 2007;13(3):939-43.

52. Zielie PJ, Mobley JA, Ebb RG, Jiang Z, Blute RD, Ho SM. A novel diagnostic test for prostate cancer emerges from the determination of alpha-methylacyl-coenzyme a racemase in prostatic secretions. J Urol 2004;172(3):1130-3.

53. Laxman B, Tomlins SA, Mehra R, Morris DS, Wang L, Helgeson BE, Shah RB, Rubin MA, Wei JT, Chinnaiyan AM. Noninvasive detection of TMPRSS2:ERG fusion transcripts in the urine of men with prostate cancer. Neoplasia 2006;8(10):885-8.

54. Masood A Khan, MD and Alan W Partin. Evolving Role of Pro-PSA as a New Serum Marker for the Early Detection of Prostate Cancer. Rev Urol 2002;4(4):198-200.

55. Mikolajczyk SD, Millar LS, Wang TJ. "BPSA," a specific molecular form of free prostate-specific antigen, is found predominantly in the transition zone of patients with nodular benign prostatic hyperplasia. Urology 2000;55(1):41-5.

56. Mikolajczyk SD, Marks LS, Partin AW. Free prostate-specific antigen in serum is becoming more complex. Urology 2002;59(6):797-802.

57. Nurmikko P, Väisänen V, Piironen T, Lindgren S, Lilja H, Pettersson $\mathrm{K}$. Production and characterization of novel anti-prostate-specific antigen (PSA) monoclonal antibodies that do not detect internally cleaved Lys145-Lys146 inactive PSA. Clin Chem 2000;46(10):1610-8.

58. Leman ES, Cannon GW, Trock BJ, Sokoll LJ, Chan DW, Mangold L, Partin AW, Getzenberg RH. EPCA-2: a highly specific serum marker for prostate cancer. Urology 2007;69(4):714-20.

59. Perner S, Hofer DM, Kim R, Shah RB, Li H, Möller P, Hautmann RE, Gschwend JE, Kuefer R, Rubin MA. Prostate-specific membrane antigen expression as a predictor of a prostate cancer progression. Hum Pathol 2007;38(5):696-701.

60. Whitaker HC, Warren AY, Eeles R, Kote-Jarai Z, Neal DE. The potential value of microseminoprotein-beta as a prostate cancer biomarker and therapeutic target. Prostate 2010;70(3):333-40.

61. Tomlins SA, Rhodes DR, Perner S, Dhanasekaran SM, Mehra R, Sun XW, Varambally S, Cao X, Tchinda J, Kuefer R, Lee C, Montie JE, Shah RB, Pienta KJ, Rubin MA, Chinnaiyan AM. Recurrent fusion of TMPRSS2 and ETS transcription factor genes in prostate cancer. Science 2005;310(5748):644-8.

62. Hessels D, Smit FP, Verhaegh GW, Witjes JA, Cornel EB, Schalken JA. Detection of TMPRSS2-ERG fusion transcripts and prostate cancer antigen 3 in urinary sediments may improve diagnosis of prostate cancer. Clin Cancer Res 2007;13(17):5103-8.

63. Graves HC, Sensabaugh GF, Blake ET. Postcoital detection of a malespecific semen protein. Application to the investigation of rape. $\mathrm{N}$ Engl J Med 1985;312:338-43.

64. Sağlam HS, Köse O, Özdemir F, Adsan O. Do the values of prostate specific antigen obtained from fresh and dried urine reflect the serum measurements. Urology. 2013;5:99-101.

65. Irani J, Salomon L, Soulié M, Zlotta A, de la Taille A, Doré B, Millet C. Urinary/serum prostate-specific antigen ratio: Comparison with free/total serum prostate-specific antigen ratio in improving prostate cancer detection. Urology. 2005;65:533-7.

66. Chwatko G, Forma E, Wilkocz J, Głowacki R, Jóźwiak P, Różański W, Bryś $M$, Krześlak $A$. Thiosulfate in urine as a facilitator in the diagnosis of prostate cancer for patients with prostate-specific antigen less or equal $10 \mathrm{ng} / \mathrm{mL}$. Clin Chem Lab Med 2013;51:1825-31

67. Jung K, Reszka R, Kamlage B, Bethan B, Stephan C, Lein M, Kristiansen $\mathrm{G}$. Tissue metabolite profiling identifies differentiating and prognostic biomarkers for prostate carcinoma. Int J Cancer 2013;133(12):2914-24.

68. Hemminki K, Ji J, Försti A, Sundquist J, Lenner P. Concordance of survival in family members with prostate cancer. J Clin Oncol. 2008;26(10):1705-9.

69. Gudmundsson J, Besenbacher S, Sulem P, Gudbjartsson D, Olafsson I, Arinbjarnarson S. Genetic correction of PSA values using sequence variants associated with PSA levels. Sci TransI Med 2010;2(62):62-92

70. Carter BS, Bova GS, Beaty TH, Steinberg GD, Childs B, Isaacs WB Walsh PC. Hereditary prostate cancer: epidemiologic and clinical features. J Urol 1993;150(3):797-802.

71. Bookstein R, Totowa NJ. Tumor suppressor genes in prostate cancer. In: Bookstein R, Totowa NJ, editors. Prostate cancer: biology genetics and the new therapeutics. Humana Press; 2001. p. 61-93.

72. Thompson EB. The many roles of c-Myc in apoptosis. Annu Rev Physiol 1998;60:575-600. 
73. Sato K, Qian J, Slezak JM, Lieber MM, Bostwick DG, Bergstralh EJ, Jenkins RB. Clinical significance of alterations of chromosome 8 in high-grade, advanced, nonmetastatic prostate carcinoma. J Nat Cancer Inst 1999;91(18):1574-80.

74. Karayi MK1, Markham AF. Molecular biology of prostate cancer. Prostate Cancer Prostatic Dis. 2004;7(1):6-20.

75. Sanchez KM, Sweeney CJ, Mass R, Koch MO, Eckert GJ, Geary WA Baldridge LA, Zhang S, Eble JN, Cheng L. Evaluation of HER-2/neu expression in prostatic adenocarcinoma: a requested for a standardized, organ specific methodology. Cancer 2002;95(8):1650-5.

76. Lara PN, Jr, Meyers FJ, Gray CR, Edwards RG, Gumerlock PH, Kauderer C, Tichauer G, Twardowski P, Doroshow JH, Gandara DR. HER-2/neu is overexpressed infrequently in patients with prostate carcinoma. Results from the California Cancer Consortium Screening Trial. Cancer 2002;94(10):2584-9.

77. Catz SD, Johnson JL. BCL-2 in prostate cancer: a minireview. Apoptosis 2003;8(1):29-37.

78. McDonnell TJ, Troncoso P, Brisbay SM, Logothetis C, Chung LW, Hsieh JT, Tu SM, Campbell ML. Expression of the protooncogene bcl-2 in the prostate and its association with emergence of androgen-independent prostate cancer. Cancer Res 1992;52(24):6940-4.

79. Reiter RE, Gu Z, Watabe T, Thomas G, Szigeti K, Davis E, Wahl M, Nisitani S, Yamashiro J, Le Beau MM, Loda M, Witte ON. Prostate stem cell antigen: a cell surface marker overexpressed in prostate cancer. Proc Natl Acad Sci USA 1998;95(4):1735-40.

80. Gu Z, Thomas G, Yamashiro J, Shintaku IP, Dorey F, Raitano A, Witte ON, Said JW, Loda M, Reiter RE. Prostate stem cell antigen (PSCA) expression increases with high gleason score, advanced stage and bone metastasis in prostate cancer. Oncogene 2000;19(10):1288-96.

81. Hughes C, Murphy A, Martin C, Sheils O, O'Leary J. Molecular pathology of prostate cancer. J Clin Pathol 2005;58(7):673-84

82. Bookstein R, MacGrogan D, Hilsenbeck SG, Sharkey F, Allred DC. p53 is mutated in a subset of advanced-stage prostate cancers. Cancer Res 1993:53(14):3369-73.

83. Rogler A, Rogenhofer M, Borchardt A, Lunz JC, Knoell A, Hofstaedter F, Tannapfel A, Wieland W, Hartmann A, Stoehr R. P53 codon 72 (Arg72Pro) polymorphism and prostate cancer risk: association between disease onset and proline genotype. Pathobiology 2011;78(4):193-200.

84. Sun H, Lesche R, Li DM, Liliental J, Zhang H, Gao J, Gavrilova N, Mueller B, Liu X, Wu H. PTEN modulates cell cycle progression and cell survival by regulating phosphatidylinositol 3,4,5,-trisphosphate and Akt/protein kinase B signaling pathway. Proc Natl Acad Sci USA 1999;96(11):6199-204.

85. Hughes C, Murphy A, Martin C, Sheils O, O'Leary J. Molecular pathology of prostate cancer. J Clin Pathol 2005;58(7):673-84.

86. Doherty AP, Bower M, Smith GL, Miano R, Mannion EM, Mitchell H, Christmas TJ. Undetectable ultrasensitive PSA after radical prostatectomy for prostate cancer predicts relapse-free survival. Brit J Cancer 2000;83:1432-6.

87. Nakamura M, Hasumi H, Miyoshi Y, Sugiura S, Fujinami K, Yao M, Kubota $Y$, Uemura $\mathrm{H}$. Usefulness of ultrasensitive prostate-specific antigen assay for early detection of biochemical failure after radical prostatectomy. Int J Urol 2005;12:1050-4.

88. Shen S, Lepor H, Yaffee R, Taneja SS. Ultrasensitive serum prostate specific antigen nadir accurately predicts the risk of early relapse after radical prostatectomy. J Urol 2005;173:777-80.

89. Sakai I, Harada K, Kurahashi T, Muramaki M, Yamanaka K, Hara I, Inoue TA, Miyake H. Usefulness of the nadir value of serum prostatespecific antigen measured by an ultrasensitive assay as a predictor of biochemical recurrence after radical prostatectomy for clinically localized prostate cancer. Urol Int 2006;76:227-31.

90. Kinoshita H, Kamoto T, Nishiyama H, Nakamura E, Matsuda T, Ogawa $O$. Prostate specific antigen nadir determined using ultra-sensitive prostate specific antigen as a predictor of biochemical progression after radical prostatectomy in Japanese males. Int J Urol 2007;14(10):930-4.

91. Eisenberg ML, Davies BJ, Cooperberg MR, Cowan JE, Carroll PR Prognostic implications of an undetectable ultrasensitive prostate-specific antigen level after radical prostatectomy. Eur Urol 2010;57(4):622-9.

92. Yoshida T, Matsuzaki K, Kobayashi Y, Takeda K, Nakayama M, Arai Y, Kakimoto K, Nishimura K. Usefulness of postoperative nadir prostate-specific antigen value by ultrasensitive assay as a predictor of prostate-specific antigen relapse for pathological T3 or positive surgical margins after radical prostatectomy for prostate cancer. Int Urol Nephrol 2012;44(2):479-85.

93. Vesely S, Jarolim L, Schmidt M, Minarik I, Dusek P, Babjuk M. Parameters derived from the postoperative decline in ultrasensitive PSA improve the prediction of radical prostatectomy outcome. World J Urol 2013;31(2):299-304. 